\title{
Impact of Using information and Communication Technology (ICT) in Open Distance Learning (ODL) as an empowerment tool for women in Zimbabwe.
}

\author{
Nyatsanza Taurai $\mathrm{D}^{1}$, Mtezo J \\ ${ }^{\text {I}}$ (Student Management, Zimbabwe Open University, Zimbabwe) \\ ${ }^{2}$ (Administration, Zimbabwe Open University, Zimbabwe)
}

\begin{abstract}
Women constitute about 52\% of the total world population, but they form only nine percent of the total productive work force mainly because women have lagged behind in education. Distance education has provided women with an opportunity to redress the situation. ODL is endowed with high flexibility and can meet the demands of education for women of all persuasions which the conventional education system is unable to meet. Empowerment is an active multi-dimensional process which enables women to realize their full potential in all spheres of life. The study examined how ICTs have influenced the empowerment of women through $O D L$ in Zimbabwe. The population for the study were Zimbabwe Open University women alumnifrom the ten regions of Zimbabwe. The study was qualitative and used a sample of ten purposively selected women from the ten Regions of the Zimbabwe Open University. Key informant interviews and nominal group discussions were held using internet and the social network forums. The study found out that,the use of ICT in Open and distance learning hasequippedwomen intellectually and empoweredthemthrough acquisition of skills and knowledge. ICT in ODL has rendered women more informed, autonomous and liberated.
\end{abstract}

Keywords: Developing Countries, Empowerment, Information and communication technology (ICT) Open and distance learning $(O D L)$,

\section{Introduction}

Open and distance learning is one of the most rapidly growing fields of education, and its potential impact on all education delivery systems has been greatly accentuated through the development of ICT-based technologies, and in particular the World Wide Web.This study was motivated by the potentially powerful role that information and communication technologies (ICTs) can play in the empowerment of women who study through ODL in Zimbabwe and other developing countries in Africa. The study reviewed literature on ICTs and empowerment of women, drawing upon several studies to identify practices that underlie empowering of women through ICTs in Zimbabwe. The insights developed in this study should be useful both for purposes of effective program development and policy design. ICTs in ODL are increasingly being promoted as a key solution for comprehensive national development, poverty eradication and the empowerment of women.

\section{Background to study}

The Declaration of Agreement in Support Of Girls and Women in Information and Communication Technology, introduced at the United Nations World Summit on the Information Society in Tunis, Tunisia on November 16, 2005, stressed that "ICT allows women increased participation in political, social, and economic arenas and supports empowerment for themselves, their families, and their communities."(UNESCO 2012). However, it also warns that "failing to recognize and remedy women's severe under-representation in the development of ICTs and ICT policy, including both access and leadership, limits our ability to advance our global society." Many open universities have emerged to recruit large numbers of new learners, while, an increasing number of traditional universities have begun to offer their programmes also through distance education (Dimevski and Kokol, 2004). A review of research literature reaches the same conclusion that with electronic tools, people can learn virtually anytime, at any place they choose without obstacles in place, time and social status (Velzeoer, 1996; Greer and Murtaza, 2003; and Keegan, 2004). Thus, the importance of information and communication technologies (ICTs) and e-learning in promoting open, distance and flexible education cannot be over-emphasized. The use of ICTs has great potential of empowering women. A number of researches done in countries like Uganda, Egypt, India and many others indicate that ICTs have actually empowered certain groups of women that have gone through certain programmes. This paper seeks to find out the impact the use of ICTs has had on a sample of women that have gone through ZOU ODL programmes. 


\section{Statement of the problem}

How has the use of ICTs in ODL empowered women in Zimbabwe?

\section{Research objectives}

The study seeks to review the impact of using ICTs in open and distance learning to empower women in Zimbabwe with reference to the Zimbabwe Open University (ZOU).It also seeks to find out the impact the use of ICTs has had on the success of the women under study.

\section{Research questions}

What ICT skills has ZOU imparted to its female students? How have female students in ODL used ICT skills to empower themselves? What are the success stories of these women and what lessons can be drawn from their experiences? What strategies should be put in place to increase access and the use of ICT among women?

\section{Significance of study}

The importance of this study is that, results on the impact of ICTs in ODL as an empowering tool for women would provide critically needed information for planning programmes to enhance the attainment of gender equity and empowerment for women.

\subsection{A brief History of ODL in Zimbabwe.}

\section{Review of Related Literature}

Atindependence there was only one university in Zimbabwe, the University of Zimbabwe. Many people had been denied access to higher education. The Williams commission of 1981 recommended the devolution of higher education and the introduction of open and distance education. The Zimbabwe Open University is the only open and distance learning university in Zimbabwe. It was established through an Act of Parliament (Zimbabwe Open University Act: Chapter 25:20) in 1999. Its main objective was to impart knowledge, competencies and skills necessary for the development of competitive human resources, using well developed open and distance learning methods. The Zimbabwe Open University started off as a Centre for Distance Education established in 1993 by the University of Zimbabwe in the Department of Educational Administration. The Centre for Distance Education developed to become the University College of Distance Education (UCDE) in 1996 andfrom 1 March 1999, it became the Zimbabwe Open University ( ZOU) through an Act of Parliament (the Zimbabwe Open University Act: Chapter 25:20).

Since then, ZOU has introduced many programmes and is continually improving its delivery mode to include ICT packages. Students are introduced to basic ICT skills which they then further develop on their own to become proficient in their use. Each of the programmes offered by ZOU has a course for basic computer skills as follows:

\begin{tabular}{|l|l|}
\hline APPLICATION & SKILLS TAUGHT \\
\hline MS Word & Creating, editing, saving and filing of documents. \\
\hline MS Excel & Creating of spread sheets, design of graphs, diagrams and tables. \\
\hline Internet Access & $\begin{array}{l}\text { Creation of accounts, Surfing, down loading, saving and filing of } \\
\text { documents, use of e-books }\end{array}$ \\
\hline Power Point & $\begin{array}{l}\text { Creation of slides, editing, deleting, animating, inserting of photos } \\
\text { and charts }\end{array}$ \\
\hline
\end{tabular}

\subsection{The Conceptual Framework}

Siwal (unpublished) argues that if we say we want to see people empowered, we consider them to be currently disempowered by the way power relations shape their choices, available resources and decision making. Empowerment is personal, cannot be bestowed on one by another. It is a process and not an event. It can never be absolutely achieved. It can only be described in time, space and level. Empowerment refers to a process, whereby individuals gain strength, confidence and visions to work for positive changes in their lives (Eade 1997). According to United Nations the concept of women empowerment entails the following:

- Women's sense of self worth

- Their right to have and determine choices

- Their right to have access to opportunities and resources

- Their right to have power to control their lives, both within and outside the home

- Their ability to influence the direction of social change to create a more just social and economic order.

The concept of women empowerment has been used and defined by numerous scholars and development agencies. In this paper woman empowerment is described as the process for developing skills for the acquisition of knowledge and resources for women. The importance of this study is that, results on the impact of ICTs in 
ODL as an empowering tool for women will provide critically needed information for planning programmes to enhance the attainment of gender equity and empowerment for women.

\subsection{Unpacking ICT}

The range of technologies under this acronym ICTs are, communication devices and applications which include cellular phones computers (hard ware and software), print media, radio, television the Internet and many others (UNESCO 2002). UNDP (2002), states that ICTs, are both traditional (such as radio, television, print and fax) and new devices such as the mobile phone, laptops and desktops. For the purpose of this study, ICTs is defined as any communication device and application, that enables distance learning, communication, access to information and to some extent resources. For one to be able to use and benefit from ICTs there is need for Computer literacy which can be defined as "the knowledge and ability to use computers and related technology efficiently". It can also refer "to the comfort level someone has with using computer programmes and applications" (UNESCO 2002).

\subsection{ICTs and Open and Distance Learning}

The growth in open distance learning has been attributed to the advancement in the field of ICTs (Hawkey, 2002). Before this development teaching and learning was done through printed materials and regular mails. Because of globalization and ICTs, teaching and learning changed. The present changing economy and the proliferation of modern technologies call for change in demand for education and the approach to teaching and learning and the delivery of education. Current emphasis in open distance learning is the use of modern ICT. This is done either through integrated media approach, multi-site learning system, and e-learning or through virtual classroom. Other methods include written materials, interactive television/radio instruction, videos, audio tapes, and CDS to the learners. The e-mail, the web and video conferencing over broadband network connections are currently being used in to transmit learning materials to students in ODL (UNDP 2002).Currently ZOU uses CDs, DVDs, printed material e-brarye-mails, facebook, ,sms and other social networks (ZOU undated).

\subsection{ICT in ODL as women empowerment tool}

According to UNESCO (2002) limitation in the access of many women to education opportunities which would enhance empowerment of women is due mainly to the inability of women and the tutor to be in face to face contact. UNESCO (2002) highlighted that there were over 900 million adults in the whole world who were deprived access to education, because they were required to be present in a conventional classroom before they could gain access to quality education. In Zimbabwe women constitute $52 \%$ of the population and most of them were marginalised due to the colonial educational bottle neck system and cultural practises (CSO 2012). In addition limitations in human, material and financial resources, made it impossible for the traditional conventional approach of teaching in the classrooms to satisfy the demand.

Open and Distance learning reflects both the fact that all or most of teaching is conducted by someone removed in time and space from the learner, and that the mission aims to include greater dimensions of openness and flexibility, whether in terms of access, curriculum or other elements of structure. The desire to anchor as much as possible to the train of globalization demands that all sectors of society must be literate and this kind of mass education can only be afforded through the use of ICT in distance-learning.

The concept of ICT in ODL is a scheme that affords the opportunity to effectively transmit educational benefits to all people cheaply and more effectively, especially women denied access on the basis of their gender roles and other social consideration. Research done in Nigeria on women empowerment (Olakulehin and Olugbenga 2001) noted that women through ICT in ODLwere afforded the opportunity to pursue the gift of knowledge without contradicting any societal dictates.

The use of ICT in ODL as a women empowerment strategy can be viewed from the fact that it straddles so many facets of the social system. ICT in ODL benefits women who are full time house wives, many of who have never had access to formal education or had to give up school at early stages of their lives due to many reasons some of which include early pregnancies and lack of resources to send them to school. These women according to (Olakulehin and Olugbenga 2001) were not usually enthusiastic about formal education because their husbands would want them to sit at home and take care of the home and the children. As a result most of these women were unable to leave their families to go a conventional university system.

ICT in ODL allows women then to be at home and study for a programme without jeopardising their marriages or abandoning their children. According to UNESCO (2012) and Azikiwe (1992) women education is essential for rural development. Women are not well equipped to contribute effectively to socio economic issues because of illiteracy.

As said earlier, in Zimbabwe most women have been denied the access to formal training provided by universities and colleges due of cultural and sometimes religious norms (CSO 2012). Because of ODL these 
women can now have access to education through the use of ICT. The ICT in ODL learning approach allows women to pursue their education at a safe distance from the tutors. They can study; e-mail assignments, have research project supervision on line.

The African culture preferred only the husband to pursue further education for improvement. Working women tend to live unfulfilled lives, having their dreams aborted prematurely. After a college degree, a working woman finds herself in marriage and the demands of child birth make her abandon going back to school. The family places many social demands on working women. As a result of the use of ICT in ODL benefits the working women in Zimbabwe who otherwise would have to abandon their families and their work to pursue better educational qualifications for them to enhance chances of their career progression. ODL allows them to pursue qualitative education that improves their sense of self-esteem in the estimation of their family, friends and husbands. These can be achieved without jeopardising either the important family relationship or the relatively responsible position in their place of work..

\subsection{Impact of ICT to women}

Studies in Bolivia by Wamala (2012) on the use of ICT by indigenous women found out that an increasing number of female leaders had been able to gain key political positions at local, regional and national levels. Media such as Skype gave female indigenous leaders an "easier and cheaper" way to connect to each other; which in turn advanced their confidence and unity in speaking about issues most pertinent to them (Wamala 2012). Online platforms such as blogs and wikis as well as traditional media such as radio and television had enabled women in Bolivia to communicate their message to a wider audience. According to Wamala (2012) the impact of these efforts was underscored in the fact that a number of women's demands were addressed when a local leader in Confederation of Indigenous Peoples of Eastern Bolivia assumed a national leadership role.

The project 'Empowering self-help' groups in Kenya and India through ICT for better education and alternative livelihood activities.Recounting the global phenomenon of ICT on ODL in Africa, Fagbamiye (2006), highlighted that ICTs had that in particular women now had access to quality learning. Emerging ICT had turned the global village into a global knowledge village (UNESCO 2002)

\subsection{Contribution of ICTs to Women's Economic Empowerment}

The empowering effects of the use of ICTs for women and other community members have been indicated by several researchers (Daws, 1997; Harcourt, 1999; Milio, 1996 ;) An online discussion on "Information and communication technologies and their impact on and use as an instrument for the advancement and empowerment of women :( 17 June to 19 July 2002) summed up the benefits of using ICTs to improve the economic status of women in some areas. The following observations were made:

Use of ICTs:

- increased the ability of women to work from home;

- Improved employment opportunities for women;

- Increased ability of informal sector women to move to the formal sector;

- Improved global market access for craftswomen through e-commerce;

- Transformed women' traditional gender roles;

- Improved access of women, especially rural women, to distance learning and distance work programs;

- Improved the ability to share experiences among women's organisations concerned with the economic well-being of women in the informal sector; and

- Increased ability to avoid gender bias by having a gender-opaque medium.

\subsection{Research design}

\section{Research Methodology}

The study was qualitative by nature. World Bank (2002) argues that qualitative methods can be used to uncover and understand what lies beyond any phenomenon about which little is yet known. This enabled the researchers to collect rich descriptive data from the information rich participants.

\subsection{Sample}

A sample of ten successful women who had studied with ZOU was purposively selected, one from each of the ten regions of Zimbabwe. The small but focused sample was used since there was need for comprehensive investigation of the impact of the use of ICTs by the women in ODL. 


\subsection{Data collection}

The focus group discussions enabled the researchers to collect in-depth understanding, experiences and perceptions of the participants on the use of ICTs and how they had benefitted from them. Emphasis was on emergent discovery, exploration, and description. The study used key informant interviews through social chats, nominal group discussions technique through social chats. Theanalysis explored three themes; access, freedoms, and resources to communicate, which are analytical categories

\subsection{ICT resources used by women in ODL in Zimbabwe}

\section{Findings and Discussions}

The study found out that all the tenwomen had used and were still using:

- Internet,

- Emails,

- DVDs/CDs,

- Facebook,

- mobile phones, Skype and twitter,

- digital cameras,

- television and radio,

- Laptop and desktop computers,

- e books,

- Educational software.

\subsection{Success stories from some of theparticipants}

1. Pastor (Studied for Bachelor of Science Honours inCounselling degree)

"I use a tablet and it has become my best friend. I have downloaded various bibles for comparison on my tablet. I learnt to surf the web, create email accounts, and form social chat groups on face book and other social networks. The social groups I created have a following of over two hundred church members, I also chat with other pastors to share ideas, best practices for our congregations. The internet also helps me keep abreast with world events. I get a lot of assistance for my sermons from commentaries on various websites. I have saved over twenty marriages through on line counselling. I have also created a daily reflection chat forum were I share gospel reflection with my congregation every morning. The use of ICT has helped me keep in touch with my congregation. This has reduced my physical visits to church members and has broken communication barriers with people who require counselling and were restricted because cultural inhibitions".

2. Headmistress of a Private School (Studied for Bachelor of Education and Master of Education in Educational Management degrees)

"I have computerised my whole administrative system and created a data base for all students where fees payments, biodata and results are stored. Time tables and work plans have now been computerised. It is easier to produce a new timetable from a soft copy than from previous hard copies. I used to have a timetable committee for making this but now I can do it using the ICT skills I learnt inODL. My school participates in posting educational articles on a platform created by schools in our district. Students access the information on this website. I e-mail parents and guardians notices and minutes of meetings, send progress and examination reports of students. Open and distance education has really helped me progress in my career and ICTs are making my work a lot easier and enjoyable.

\section{Business woman (Studied for an Executive Diploma in BusinessLeadership)}

"I am a mother of 2 and live with my family. I got married soon after my O'Levels. My husband is older than me and has always believed in taking care of me and the family. I always felt that I wanted to do something for myself. The idea of being 'kept' forever worried me. My husband allowed me to join the Executive Diploma in Business leadership programme because it would it would not affect my responsibilities at home. I used my cell phone to communicate with the programme coordinators and tutors. I was then introduced to basic computers. I found this fascinating. Back home I began to take interest in my husband's business .At first he did not take me seriously. With my newly acquired skills I started doing spread sheets for his accounts. This caught his attention and he started giving responsibilities in his business.

Eventually he gave me money to start my own business. I have since developed further ICT skills. I have used my mobile phone to follow market prices and order some of my stock on line. I have created a shop on my mobile phone and use social chat spots like face book to advertise my products. I have a database of my customers whom I notify with textmessages the arrival of any new products and any special offers. I get 
immediate feedback from these customers using my mobile phone. Thanks to ZOU for offering distance education, introducing me to ICTs and giving me a new lease of life. Now the sky is the limit for me"

4. Nursing sister (Studied for a Bachelor of Science in Nursing Science degree)

I trained as a nurse and worked in that capacity for fifteen years. It was always my wish to further my education but because of family commitments it was not possible. Open Distance learning offered by ZOU gave me the opportunity I had been yearning for. I read all my modules from home. I communicated with my tutors using my cell phone by sending messages. Since there was very little contact time with the tutors, my colleagues and I created a chat forum where we discussed issues or difficult topics, assisted one another with resources for assignments. I used the internet on my husband's laptop for research. I developed more ICT skills which I now use in my new positions.

I have set up a surgery where I contract doctors to come and examine patients. I have created data base of patients, doctors (general practioners and specialists) that I can call on. I have also grouped the patients according to conditions. I also keep records of payment. We dispense some medicines and we use the internet to get best prices. I also do a lot of reading to keep abreast with developments in the medical world.

I am also head of the health committee at my church. We have a chat forum with other health professionals where we share information and discuss issues that need attention at our church. We use ICTS to sensitize women in our parish about family planning issues, HIV and AIDS issues, primary and maternal health, infant mortality, cancer and other diseases.

I am also into e-business; I bought my car online from Japan. This saved me lot money that would have been charged by agencies. I use Eco cash to send money to my parents in rural areas. I use e-banking to pay my bills and do some purchases. ICTs have really empowered me.

5ProgrammeCoordinator (Studied for aBachelor ofScience inCounselling degreeand Masters of Science in Counseling. She is now a doctoral candidate)

"I trained as a primary school teacher, got married and started a family. I could not go back to school even though I really wanted to. My husband did not object but I dared not ask. My socialisation was that family responsibility took precedence over everything else. I did not want to embarrass my husband by abandoning my family in case he became laughing stock.

The introduction of ODL in Zimbabwe gave me an opportunity to learn from home. I grabbed it and have never looked back. ICTs facilitated my learning through communication with my tutors and colleagues. I learnt how to use e-books, and e-journals for research. I have become an avid researcher and have published in a number of journals. Currently I am reading for my doctorate degree which I hope to complete soon.

ICTs helped me in my work by facilitating easy communication with my students. I do a lot of on line research to keep abreast with trends in counseling so that I can assist my students. I also supervise part-time tutors. I use power point presentations for my meeting with part-time tutors and tutorials with students.

My observation, however, is that although ZOU introduces basic ICT skills to all students, the only device that most students can afford is the mobile phone. Many students still do not have access to laptops and desk tops. This limits students access to information particularly women. There is great need for availing ICT hard ware to make information more accessible to women.

6. House wife (Studied for a Bachelor of Science Honours in Psychology degree)

"ICTs in ODL have enabled me to continue in contact with my study circle friends. With the study group we formed during my distance learning we formed a chat group and a group on Facebook where we shared recipes and ways of improving our homes. I have managed to generate some income on a monthly basis even though I am not in formal employment. I bake cakes and with the help of my friends I have a ready market.

7. Entrepreneur (Studied for Bachelor of Commerce inMarketing degree)

"I created my Face book page where I obtain information about market prices of the inputs for my food processing activities and for the sale of my produce. I prefer use of my cell phone to the computers because of the ease of transport.

8. Non-governmental Director (Studied for Bachelor of Science Honours in Special Education)

"I lead an organisation of over fifty persons with various impairments. With the skills I gained through using ICTs in ODL I have been able to sensitise people with disabilities (visual impairment, Hearing Impairment) about family planning issues, diseases HIV and AIDS issues. This I have been able to do using special computer programmes that carry the message in the language understood by persons with specific disabilities."

9 Single Parent (Studied for a Master of Science in Peace, Leadership and Conflict Resolution) 
"Equipped with ICT skills I gained during my ODL years I gained access tolots of useful information. I was suffering in silence and needed help and advice to stand up for myself. "The online service clinic is very beneficial and accessible to women who need help to handle violent domesticabuse" I learned that I have rights, that women can go ahead in life alone, and we do not have to stay in abusive relationships. I have more knowledge on how to defend myself and to assert my rights as a person

For many of abused women in Zimbabwe the online network provided a sense of security. Using pseudonyms enabled them to share their experiences, and open up to other victims about their problems without worrying about being found out. Women gained self-confidence through knowledge of their rights. Thanks to ICTs in ODL.Some victims found the strength to escape the isolated and repressed existence of victims of domestic violence.

\subsection{Summary of the Benefits of using ICTs in ODL from the partcipants}

\begin{tabular}{|c|c|c|}
\hline Theme & Empowerment & Impact \\
\hline Access & $\begin{array}{l}\text { - } \quad \text { Downloaded various bibles for comparison. } \\
\text { - } \quad \text { Improved, easy and cheap communication } \\
\text { Engage in academic, business and social discussions }\end{array}$ & $\begin{array}{ll}- & \text { Keep abreast with world } \\
\text { events. }\end{array}$ \\
\hline Freedom & $\begin{array}{l}\text { - Create email accounts. } \\
\text { - } \quad \text { Form social chat groups on social networks. } \\
\text { chat with other pastors to share ideas, best practices for our } \\
\text { congregations }\end{array}$ & $\begin{array}{ll}\text { - } & \text { ability to lead } \\
\text { - } & \text { following of over } 200 \text { church } \\
\text { - } & \text { members } \\
\text { - } & \text { Elime counselling } \\
\text { - } & \text { Psychososocial support } \\
\text { - } & \text { Rights awareness, } \\
\text { - } & \text { Advocacy on women issues }\end{array}$ \\
\hline Resources & $\begin{array}{ll}\text { - } & \text { flexibility } \\
\text { - } & \text { accessibility } \\
\text { - } & \text { avuitable access } \\
& \text { and employment }\end{array}$ & $\begin{array}{ll}\text { - } & \text { Cost benefit } \\
\text { - } & \text { Started own businesses } \\
& \text { Functional and } \\
\text { - } & \text { empationalliteracy to women } \\
\text { employment }\end{array}$ \\
\hline
\end{tabular}

ICTs in ODL in Zimbabwe created access to learning for indigenous women and as well provided functional literacy and livelihood skills, relevant in empowering women. From the results above ICTs in ODL would go a long way in increasing on the literacy level of women in Zimbabwe. This concurs with UNDP (2002) assertion that education is the most effective strategy for promoting women empowerment. The United Nations report on human development and Tunis declaration on use of ICTs by women also confirm the findings as they highlighted that in sub-Saharan Africa education seems to be the only effective means of empowering women. The findings generally highlights that the use of ICTs in ODL for women is a poverty reduction scheme. Issues relating to politics, peace and governance within their societies, primary health maternal and infant mortality as well as environmentally sustainability to agricultural and health related information, improved communication within the community, and confidence building. Livelihoods are also improved by the increased access to information and to structures of communication within the community, most notably the radio and the ability to ask for support and advice via the mobile phone

\section{Conclusions}

The issue of culture, social attitudes and values has a resultant effect on the utilisation of ICTs in distance education. The overall use of ICTs in ODL has empowered women. Internet resources have created a greater awareness of governance issues and technical forms of communication. Therefore, ICTs have a positive impact on the empowerment of women.Hence the use of ICTs in ODL by women should be considered both as a necessity and an opportunity to empower them in this era of globalization. Though the research was limited to women, the functional benefits and advantages of ICTS in ODL can be extended to other vulnerable groups of the society. ICT in ODL holds special implication for the women in Zimbabwe. Lots of informal trading women, itinerant businesswomen, women in the rural areas, working women could be empowered by using ICTs.

\section{Recommendations}

Given the current trend towards global partnership and the exclusive nature of programmes of traditional institutions, ICTs in ODL provide better alternatives among women and the marginalised (people 
like people with disabilities) for empowerment and remedies to solve educational, social, health, political, economic and environmental issues concerning them.

The concept of education for all in Zimbabwe should be matched with individual functional literacy skills acquisition for all as provided by the ICT ODL methods. This way, women would be better equipped for effective participation and performance. Considering the benefits accrued by women who used ICTs in ODL, emphasis should be placed on resource allocation and learning methodologies to expand the education of women in rural communities.

In order for ICTs and ODL to contribute to women's economic empowerment, strategic actions must address the needs of informal sector women and the needs of rural women. ODL should thus focus on programmes that:

- Train women in the use of ICTs for record keeping;

- Link ICT organisations with Women's Rights organisations

- Develop channels to allow foreign exchange trade for informal sector women

- Use ICTs to provide product, pricing and market information for informal sector women.

- Improvement ICT access to support business linkages

- provide improved e-mail access for rural women;

- Use ICTs to create markets for the products and services of rural women;

- Initiate well-supported rural ICT projects geared to women.

Finally, a more comprehensive study should be carried out on a wider sample which includes people with disabilities, although the theme and methodology of this study would still be followed.

\section{References}

[1] UNESCOOpen and Distance Learning: Trends, Policy and Strategy Considerations.(Paris. UNESCO, 2012)

[2] DimevskI, D., \& Kokol, P. ICT and Lifelong Learning, EURODL (European Journal of Open, Distance and E-Learning. Slovenia: University of Maribor, (2004). Pp. 1-6.

[3] Velzeboer, M. Globalization and the Internet, Grassroots Development - Journal of the Inter-American Foundation,(1996).Vol. 20, No 2.

[4] Keegan, D.The impact of new technologies on distance learning students, Distance Education International, Ireland ${ }_{2}$ (2004): http://eleed.campussource.de/archive/ 4/1422, retrieved on 23/6/2013

[5] Siwal,genderhttp://etheses.bham.ac.uk/3314/1/Wazed12PhD.pdf un published retrieved 20 May 2013.

[6] Eade, D. Capacity-Building. An Approach to People-Centred ICT as a tool for empowerment in Uganda(1997)

[7] UNESCO Open and Distance Learning: Trends, Policy and Strategy Considerations. (Paris. UNESCO, 2002)

[8] UNDP Gender equality and empowerment of women through ICT: (New York, 2002)

[9] Hawkey, R. The lifelong learning game: season ticket or free transfer?" Computers and Education, (2002). No. 38, pp. 5-20.

[10] United Nations Development Program (UNDP) (2002). Information, Communication and Knowledge-sharing, Gender in Development, Learning and Information Pack, UNDP, New York; http://www.undp.org/gender/infopack.htm, retrieved on 23 May $\underline{2013}$

[11] New student information handbook.(Harare: ZOU undated).

[12] CSO, Zimbabwe Demographic and Health Survey 2010-2011,(Harare:ZIMSTAT 2012).

[13] Olakulein F.K and Olugbenga D. O Distance Education as a Women Empowerment Strategy In Africa. Turkish Online Journal Of Distance Education-Tojde January 2006 Issn 1302-6488 Volume: 7 Number: 1 Article: 13.

[14] Wamala C Empoweringwomen through ICT ( 2012) Spider ICT4D series Number 4

[15 ]Fagbamiye, O. E. M. (2006). Open and Distance Learning in a Globalized World Faculty of Education Annual Lecture, Obafemi Awolowo University, Ile-Ife, Nigeria.

[16] Daws, L..An analysis of the role of the Internet in supporting rural women's leadership initiatives. Paper presented to the Sixth Women and Labour Conference, Deakin University, Geelong, 1997, 28-30 November

[17] Harcourt 1999

[18] Milio, N..Engines of empowerment: Using information technology to create healthy communities and challenge public policy. (Chicago: Health Administration Press, 1996)

[19] World Bank (2002). Monitoring and evaluation: Some tools, methods and approaches. Washington D.C World Bank Group http://www.worldbank.org/oed/ecd retrieved on 27 May 2013 